\title{
Review
}

\section{Pathological Evaluation of HER2 Overexpression: For the Treatment of Metastatic Breast Cancers by Humanized Anti-HER2 Monoclonal Antibody (Trastuzumab)}

\author{
Shinobu Umemura ${ }^{1}$, Yasutomo Sekido ${ }^{1}$, Hitoshi Itoh ${ }^{1}$ and R. Yoshiyuki Osamura ${ }^{1}$ \\ ${ }^{1}$ Department of Pathology, Tokai University School of Medicine, Isehara 259-1193
}

Received January 24, 2002; accepted February 15, 2002

For the treatment of patients with metastatic breast cancer by humanized antihuman epidermal growth factor receptor type 2 (HER2) antibody (trastuzumab), it is important to evaluate HER2 status adequately. This article overviews devel-

\author{
opments of basic and clinical research \\ for HER2 gene, and introduces general \\ agreement with the evaluation system of \\ HER2 overexpression with several com- \\ mentaries from the aspect of histochem- \\ istry.
}

Key words: Breast cancer, HER2, Trastuzumab, Immunohistochemistry, FISH

\section{Introduction}

In the past three decades, HER2 gene overexpression has attracted many basic and clinical researchers leading to an accumulation of the knowledge and techniques for practical use in the clinical field. HER2 protein is a transmembrane tyrosine kinase receptor for an unknown growth factor. HER2 overexpression is a poorer prognostic factor in breast cancers $[26,28]$ and a predicting factor for therapeutic responses [2, 8, 15, 18, 30, 37]. The HER2 receptor has also been a target of an anti-receptor agent developed recently. This commercially available humanized anti-HER 2 monoclonal antibody (trastuzumab, Herceptin ${ }^{\circledR}$; Genentech Inc.,/ Roche Inc.) has been administered to patients with HER2 positive metastatic breast cancer.

Histochemical examinations were initially applied as a research tool to study HER2 overexpression, and have become a critical step in the patient therapy. It is essential to evaluate HER2 status adequately in order to select the patients expected to benefit from trastuzumab treatment. In this article, development of basic knowledge of HER2 gene and clinical applications will be reviewed concerning the

Abbreviations: HER2, human epidermal growth factor receptor type 2; FISH, fluorescence in situ hybridization; IHC, Immunohistochemistry.

Correspondence to: Shinobu Umemura, Department of Pathology, Tokai University School of Medicine, Isehara 259-1193, Japan. relation with applied histochemical techniques.

\section{HER2}

The neu gene was identified by transfection study of DNA of nitrosoethylurea-induced rat neuroblastomas [24, 27]. Other groups isolated human erbB-related genes HER2 [6] and c-erbB-2 [25] independently. Subsequent sequence analysis and chromosomal mapping studies revealed these three genes to be identical $[6,25,36]$. HER2/c-erbB-2 gene is located on chromosome 17q21 [7, 23], and the HER2 product is a transmembrane tyrosine kinase consisting of an extracellular domain, transmembrane domain and intracellular domain. There are many ligands binding to HER1, HER 3 and HER4. EGF, TGF- $\alpha$, Epiregulin, $\beta$-cellulin, HBEGF and amphiregulin bind to HER1, Neuregulin 1 (NRG1) binds to HER3, and HB-EGF and NRG1-4 bind to HER4 [12]. However, no ligand has been found to bind to HER2 with a high affinity. Ligand-binding to HER1, HER3 and HER4 stimulates homodimer and/or heterodimer formation of these receptors as well as HER2. The intracellular domain is autophosphorylated resulting in intrinsic kinase acitivity, except for HER3 [9]. Thus, although HER2 and HER3 do not have the ability to moderate signaling alone, heterodimers including HER2-HER3 provide the means for transformation [1, 35], mitogenic activity [21], and cell motility [4] via mitogen activated protein kinase (MAPK), the c-Jun N-terminal kinase (JUNK) pathway [10], and the 
Akt pathway [38]. Slamon et al. [28] reported in 1987 that breast cancers with HER2 overexpression were associated with larger numbers of lymph node metastases and poorer prognosis. Since then, these have been many reports that erbB-2 overexpression predicts poorer prognosis in breast cancer patients [26]. The predictive value of HER2 overexpression for therapeutic response has been reported as well. Breast cancers overexpressing HER2 respond well to doxorubicin [18, 30], and resist hormone therapy (Tamoxifen) $[15,37]$ and polychemotherapy (cyclophosphamid (CPA), methotrexate and 5-fluorouracil; CMF) $[2,8]$.

\section{Trastuzumab}

Trastuzumab is produced by genetic recombination. Five percent of trastuzumab is derived from the mouse monoclonal antibody (4D5) at the region recognizing HER2 and $95 \%$ is derived from human $\operatorname{IgG}_{1}$. Host immune reaction to trastuzumab is thus minimized and the antigenbinding activity of HER2 is retained in the Fab region. Studies in tumor xenografts confirmed that murine Mab 4D5 inhibits growth of human breast cancer cells overexpressing HER2 [16] and a humanized monoclonal antibody (trastuzumab) was produced [3]. Preclinical studies [20, 31] showed that trastuzumab has the same or greater antitumor potency, and it induces antibody-dependent cellmediated cytotoxicity (ADCC) against human tumor cell lines. A phase III clinical trial demonstrated that the overall response rate to trastuzumab was $15 \%$ [5] as a single agent after chemotherapy. Administration of trastuzumab in addition to chemotherapy provided a longer time to progression, higher rate of objective response, longer survival and other clinical benefits [29].

\section{Evaluation of HER2 Overexpression}

\section{Evidence based medicine}

As the concept of "evidence based medicine" has been accepted in the clinical field, the treatment has been selected based on results of studies performed by the large number of patients but not only by individuals' experiences. Evaluation of HER2 status is also in this current. HER2 gene amplification was evaluated by Southern blotting in early studies [28] followed by IHC using CB11 or 4D5 monoclonal antibodies (clinical trial assay; CTA) in clinical trials [5, 29]. In these studies, expression was estimated by scoring system as $0,1+, 2+, 3+$ using standardized criteria, and the patients with IHC $2+/ 3+$ were listed for trastuzumab treatment. Recently, it has been emphasized that FISH is a more reliable method by the effective outcome $(41 \%)$ of trastuzumab treatment compared to IHC staining of $2+/ 3+(26 \%)$ $[33,34]$, although the patient group showing IHC $3+(35 \%)$ was treated at a similar response rate with trastuzumab [34]. The consensus at the present time is, therefore, that patients with metastatic breast cancer interpreted as $3+$ by IHC are appropriate for trastuzumab treatment, while patients with a score of 0 or $1+$ are not appropriate. Treatment of patients with breast cancers scored as $2+$ will be decided depending on several factors including patients' will, clinicians' opinion or other procedures like FISH at the present time.

\section{From the aspect of histochemistry}

Concordant rate between IHC and FISH

The concordant rate between CTA and FISH was $82 \%$ overall, and $89 \%$ between IHC $3+$ and FISH [17]. It is generally agreed that there are highly concordant rates between HER2 amplification detected by FISH and HER2 overexpression interpreted as $3+$ by $\operatorname{IHC}[11,17,22]$. For breast cancers evaluated as $2+$, consistent results between IHC and FISH were not obtained (27\%) [17].

\section{Advantages and disadvantages of IHC and FISH}

The immunohistochemical method has the advantages of lower cost, easier techniques and a shorter time for evaluation in practical routine pathology. It has been reported that the different antibodies available for HER2 protein yielded varying overexpression rates, from $17.2 \%$ to $42 \%[13,14,19]$. This variation is a major disadvantage of immunohistochemical methods. FISH is a more reliable method, but requires a more involved process, higher technical skill, higher cost and more effort to reliably evaluate. The treatment and conditions of the samples are critical for the FISH method. The kinds of fixatives, duration until fixation and period of fixation are essential for reliable results.

\section{Evaluation of HER2 protein by IHC}

Immunohistochemically HER2 protein is evaluated by population of positive cells and strength of staining (Table $1)$. When positive cells are identified in more than $10 \%$ of the population, HER2 status is evaluated as $1+, 2+, 3+$ depending on the staining strength. The consensus in the histochemical field is that strength of staining does not always correlate to the amounts of protein production, and therefore one should not evaluate the staining strength. However, it has been accepted that staining strength is well correlated to HER2 gene amplification as described above.

There are many antibodies recognizing extracellular and intracellular domain of HER2 proteins. These include TAB250 (Zymed, BioGenex) and SV2-61 $\gamma$ (Nichirei) for extracellular domain, and CB11 (Ventana, Biozac, Novocas-

Table 1. Staining pattern for evaluation of HER2 protein $*$

\begin{tabular}{cl}
\hline Score & \multicolumn{1}{c}{ Staining Pattern } \\
\hline 0 & $\begin{array}{l}\text { no staining or membrane staining is detected in less than } \\
10 \% \text { of tumor cells } \\
\text { faint or barely positive staining is detected in more than } \\
10 \%\end{array}$ \\
$2+$ & $\begin{array}{l}\text { moderate and/or incompletely circumscribed membrane } \\
\text { staining is detected in more than } 10 \%\end{array}$ \\
$3+$ & $\begin{array}{l}\text { strong and completely circumscribed membrane staining } \\
\text { is detected in more than } 10 \%\end{array}$
\end{tabular}

※ cytoplasmic staining is ignored. 


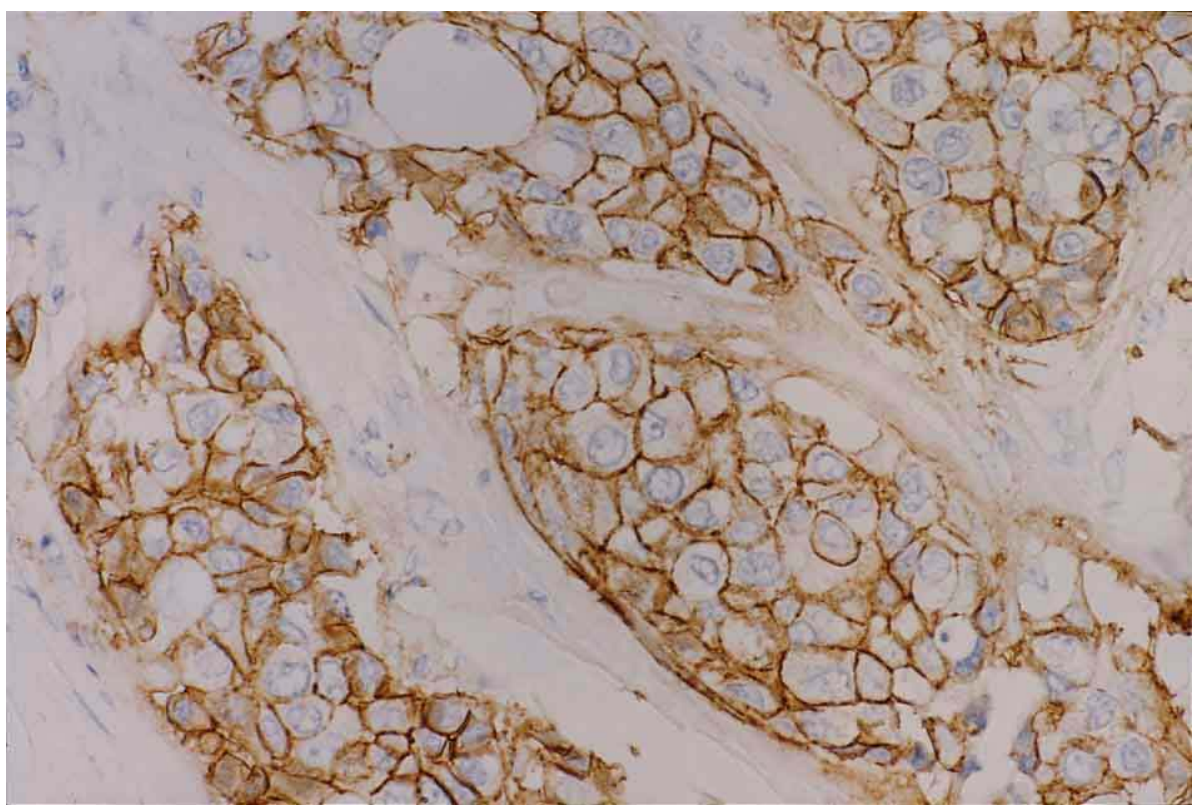

Fig. 1. Immunohistochemical features of HER2 protein. Almost all of the carcinoma cells strongly express HER2 protein at the cell border. The case was evaluated as "3+" (IHC for HER2, HercepTest).

tra, BioGenex), HercepTest (DAKO), polyclonal antibodies (Nichirei) for intracellular domain. The polyclonal antibody (DAKO) showed higher positive results and more false positive cases than CB11 or TAB250 [32].

\section{Standardization for practical use}

For the application of histochemical method to practical use, there are several matters that should be considered. Selection of method and evaluation will lead to inter-institutional and inter-observer diversities that affect the patient benefits. Commercially available staining kits may provide standardization of the staining system. A staining kit is available for IHC (HerepTest, DAKO Carpenteria, CA) (Fig. 1), and two commercially available kits are available for FISH (PathVysion ${ }^{\mathrm{TM}}$ (Vysis) and INFORM ${ }^{\mathrm{TM}}$ (Ventana)) in the United States. An atlas and a guideline produced from the trastuzumab distributing company (www.her2.org/) may be helpful for standardized evaluation. In other countries, development of quality insurance systems for immunohistochemistry in England and United States are attractive. It has been developed initially for immunohistochemical examinations of hormone receptors (estrogen receptor, progesterone receptor). These central laboratories published recommendations for adequate fixation and treatment of the sections, procedures for IHC, and appropriate evaluation system, which is a possibility for global standardization.

\section{Summary}

In this article, general agreement on application of IHC and FISH for the patients with metastatic breast cancers and the situations around HER2 gene overexpression are introduced.

\section{References}

1. Alimandi, M., Romano, A., Curia, M. C., Muraro, R., Fedi, P., Aaronson, S. A., Di Fiore, P. P. and Kraus, M. H.: Cooperative signaling of ErbB3 and ErbB2 in neoplastic transformation and human mammary carcinomas. Oncogene 10; 1813-1821, 1995.

2. Allred, D. C., Clark, G. M., Tandon, A. K., Molica, R., Tormey, D. C., Osborne, C. K., Gilchrist, K. W., Mansour, E. G., Abeloff, M., Eudey, L. and McGuire, W. L.: HER-2/neu in node-negative breast cancer: prognostic significance of overexpression influenced by the presence of in situ carcinoma. J. Clin. Oncol. 10; 599-605, 1992.

3. Carter, P., Presta, L., Gorman, C. M., Ridgway, J. B., Henner, D., Wong, W. L., Rowland, A. M., Kotts, C., Carver, M. E. and Shepard, H. M.: Humanization of an anti-p185HER2 antibody for human cancer therapy. Proc. Natl. Acad. Sci. U S A 89; 42854289, 1992.

4. Chausovsky, A., Waterman, H., Elbaum, M., Yarden, Y., Geiger, B. and Bershadsky, A. D.: Molecular requirements for the effect of neuregulin on cell spreading, motility and colony organization. Oncogene 19; 878-888, 2000.

5. Cobleigh, M. A., Vogel, C. L., Tripathy, D., Robert, N., J., Scholl, S., Fehrenbacher, L., Wolter, J. M., Paton, V., Shak, S., Lieverman, G. and Slamon, D. J.: Multinational study of the efficacy and safety of humanized anti-HER2 monoclonal antibody in women who have HER2-overexpressing metastatic breast cancer that has progressed after chemotherapy for metastatic disease. J. Clin. Oncol. 17; 2639-2648, 1999.

6. Coussens, L., Yang-Feng, T. L., Liao, Y. C., Che, E., Gray, A., McGrath, J., Seeberg, P. H., Libermann, T. A., Schlessinger, J. and Francke, U.: Tyrosine kinase receptor with extensive homology to EGF receptor shares chromosomal location with neu oncogene. Science 230; 1132-1139, 1985.

7. Fukushige, S., Matsubara, K., Yoshida, M., Sasaki, M., Suzuki, T., Semba, K., Toyoshima, K. and Yamamoto, T.: Localization of a novel v-erbB-related gene, c-erbB-2, on human chromosome 17 and its amplification in a gastric cancer cell line. Mol. Cell. Biol. 6; 955-958, 1986.

8. Gusterson, B. A., Gelber, R. D., Goldhirsch, A., Price, K. N., 
Save-Soderborgh, J., Anbazhagan, R., Styles, J., Rudenstam, C. M., Golouh, R., Reed, R., Martinez-Tello, F., Tiltman, A., Torhorst, J., Grigolato, P., Bettelheim, P., Neville, R., Burki, K., Castiglione, M., Collins, J., Lindtner, J., Senn, H.-J. for the International (Ludwig) Breast Cancer Study Group: Prognostic importance of c-erbB-2 expression in breast cancer. J. Clin. Oncol. 10; 1049-1056, 1992

9. Guy, P. M., Platko, J. V., Cantley, L. C., Cerione, R. A. and Carraway, K. L.: $3^{\text {rd }}$ Insect cell-expressed p180erbB 3 possesses an impaired tyrosine kinase activity. Proc. Natl. Acad. Sci. U S A 91; 8132-8136, 1994.

10. Hynes, N. E. and Stern, D. F.: The biology of erbB-2/neu/HER-2 and its role in cancer. Biochim. Biophys. Acta 1198; 165-184, 1994.

11. Jacobs, T. W., Gown, A. M., Yaziji, H., Barnes, M. J. and Schnitt, S. J.: Comparison of fluorescence in situ hybridization and immunohistochemistry for the evaluation of HER-2/neu in breast cancer. J. Clin. Oncol. 17; 1974-1982, 1999.

12. Jones, J. T., Akita, R. W. and Sliwkowski, M. X.: Binding specificities and affinities of egf domains for ErbB receptors. FEBS Lett. 447; 227-231, 1999.

13. Kakar, S., Puangsuvan, N., Stevens, J. M., Serenas, R., Mangan, G., Sahai, S. and Mihalov, M. L.: HER-2/neu assessment in breast cancer by immunohistochemistry and fluorescence in situ hybridization: comparison of results and correlation with survival. Mol. Diagn. 5; 199-207, 2000.

14. Lebeau, A., Deimling, D., Kaltz, C., Sendelhofert, A., Iff, A., Luthardt, B., Untch, M. and Lohrs, U.: Her-2/neu analysis in archival tissue samples of human breast cancer: comparison of immunohistochemistry and fluorescence in situ hybridization. J. Clin. Oncol. 19; 354-363, 2001.

15. Leitzel, K., Teramoto, Y., Konrad, K., Chinchilli, V. M., Volas, G., Grossberg, H., Harvey, H., Demers, L. and Lipton, A.: Elevated serum c-erbB-2 antigen levels and decreased response to hormone therapy of breast cancer. J. Clin. Oncol. 13; 1129$1135,1995$.

16. Lewis, G. D., Figari, I., Fendly, B., Wong, W. L., Carter, P., Gorman, C. and Shepard, H. M.: Differential responses of human tumor cell lines to anti-p185HER2 monoclonal antibodies. Cancer Immunol. Immunother. 37; 255-263, 1993.

17. Mass, R., Sanders, C., Kasian, C., Everett, T., Johnson, L., Anderson, S., Genentech, I. and Laboratory Corporation of America, I.: The concordance between the clinical trials assay (CTA) and fluorescence in situ hybridization (FISH) in the Herceptin $^{\mathrm{R}}$ pivotal trials. Proc. Am. Soc. Clin. Oncol. 19; 75a, 2000.

18. Paik, S., Bryant, J., Park, C., Fisher, B., Tan-Chiu, E., Hyams, D., Fisher, E. R., Lippman, M. E., Wickerham, D. L. and Wolmark, N.: erbB-2 and response to doxorubicin in patients with axillary lymph node-positive, hormone receptor-negative breast cancer. J. Natl. Cancer Inst. 90; 1361-1370, 1998.

19. Pauletti, G., Dandekar, S., Rong, H., Ramos, L., Peng, H., Seshadri, R. and Slamon, D. J.: Assessment of methods for tissue-based detection of the HER-2/neu alteration in human breast cancer: a direct comparison of fluorescence in situ hybridization and immunohistochemistry. J. Clin. Oncol. 18; 36513664,2000

20. Pegram, M. D., Baly, D., Wirth, C., et al.: Antibody dependant cell-mediated cytotoxicity in breast cancer patients in phase II clinical trials of a humanized anti-HER2 antibody. Proc. Am. Assoc. Cancer Res. Annu. Meet. 38; A4044, 1997.

21. Pinkas-Kramarski, R., Soussan, L., Waterman, H., Levkowitz, G., Alroy, I., Klapper, L., Lavi, S., Seger, R., Ratzkin, B. J., Selar, M. and Yarden, Y.: Diversification of Neu differentiation factor and epidermal growth factor signaling by combinatorial receptor interactions. EMBO J. 15; 2452-2467, 1996.
22. Ridolfi, R. L., Jamehdor, M. R. and Arber, J. M.: HER-2/neu testing in breast carcinoma: a combined immunohistochemical and fluorescence in situ hybridization approach. Mod. Pathol. 13; 866-873, 2000.

23. Schechter, A. L., Hung, M. C., Vaidyanathan, L., Weinberg, R. A., Yang-Feng, T. L., Francke, U., Ullrich, A. and Coussens, L.: The neu gene: an erbB-homologous gene distinct from and unlinked to the gene encoding the EGF receptor. Science 229; 976-978, 1985.

24. Schubert, D., Heinemann, S., Carlisle, W., Tarikas, H., Kimes, B., Patrick, J., Steinbach, J. H., Culp, W. and Brandt, B. L.: Clonal cell lines from the rat central nervous system. Nature 249; 224-227, 1974.

25. Semba, K., Kamata, N., Toyoshima, K. and Yamamoto, T.: A $\mathrm{v}$-erbB-related protooncogene, c-erbB-2, is distinct from the c-erbB-1/epidermal growth factor-receptor gene and is amplified in a human salivary gland adenocarcinoma. Proc. Natl. Acad. Sci. U S A 82; 6497-6501, 1985.

26. Seshadri, R., Firgaira, F. A., Horsfall, D. J., McCaul, K., Setlur, V. and Kitchen, P.: Clinical significance of HER-2/neu oncogene amplification in primary breast cancer. The South Australian Breast Cancer Study Group. J. Clin. Oncol. 11; 1936-1942, 1993.

27. Shih, C., Padhy, L. C., Murray, M. and Weinberg, R. A.: Transforming genes of carcinomas and neuroblastomas introduced into mouse fibroblasts. Nature 290; 261-264, 1981.

28. Slamon, D. J., Clark, G. M., Wong, S. G., Levin, W. J. and McGuire, W. L.: Human breast cancer: correlation of relapse and survival with amplification of the HER-2/neu oncogene. Science 235; 177-182, 1987.

29. Slamon, D. J., Leyland-Jones, B., Shak, S., Fuchs, H., Paton, V., Bajamonde, A., Fleming, T., Eiermann, W., Wolter, J., Pegram, M., Baselga, J. and Norton, L.: Use of chemotherapy plus a monoclonal antibody against HER2 for metastatic breast cancer that overexpresses HER2. N. Engl. J. Med. 344; 783-792, 2001.

30. Thor, A. D., Berry, D. A., Budman, D. R., Muss, H. B., Kute, T., Henderson, I. Ci., Barcos, M., Cirrincione, C., Edgerton, S., Allred, C., Norton, L. and Liu, E. T.: erbB-2, p53, and efficacy of adjuvant therapy in lymph node-positive breast cancer. J. Natl. Cancer Inst. 90; 1346-1360, 1998.

31. Tokuda, Y., Ohnishi, Y., Shimamura, K., Ando, M., Katsumata, N., Okumura, A., Ohta, M., Fujii, H., Sasaki, Y., Niwa, T. and Tajima, T.: In vitro and in vivo anti-tumour effects of a humanized monoclonal antibody against c-erbB-2 product. $B r . J$. Cancer 73; 1362-1365, 1996.

32. Tubbs, R. R., Pettay, J. D., Roche, P. C., et al.: Discrepancies in clinical laboratory testing of eligibility for trastuzumab therapy: apparent immunohistochemical false-positive do not get the message. J. Clin. Oncol. 19; 2714-2721, 2001.

33. Vogel, C., Cobleigh, M., Tripathy, D., Mass, R., Murphy, M. and Stewart, S. J.: Superior outcomes with Herceptin (trastuzumab) $(\mathrm{H})$ in fluorescence in situ hybridization (FISH)-selected patients. Am. Soc. Clin. Oncol. 20; 22a, 2001.

34. Vogel, C., Cobleigh, M., Tripathy, D., Harris, L., Fehrenbacher, L., Slamon, D., Ash, M., Novotny, W., Stewart, S. and Shak, S.: First-line, non-hormonal, treatment of women with HER2 overexpressing metastatic breast cancer with Herceptin (Trastuzumab, humanized anti-HER2 antibody). Proc. Am. Soc. Clin. Oncol. 19; $71 \mathrm{a}, 2000$.

35. Wallasch, C., Weiss, F. U., Niederfellner, G., Jallal, B., Issing, W. and Ullrich, A.: Heregulin-dependent regulation of HER2/neu oncogenic signaling by heterodimerization with HER3. EMBO J. 14; 4267-4275, 1995.

36. Yamamoto, T., Ikawa, S., Akiyama, T., Semba, K., Nomura, N., Miyajima, N., Saito, T. and Toyoshima, K.: Similarity of protein encoded by the human c-erb-B-2 gene to epidermal growth factor receptor. Nature 319; 230-234, 1986. 
37. Yamauchi, H., O’Neill, A., Gelman, R., Carney, W., Tenney, D. Y., Hosch, S. and Hayes, D. F.: Prediction of response to antiestrogen therapy in advanced breast cancer patients by pretreatment circulating levels of extracellular domain of the HER-2/ c-neu protein. J. Clin. Oncol. 15; 2518-2525, 1997.

38. Yarden, Y. and Sliwkowski, M. X.: Untangling the ErbB signalling network. Nat. Rev. Mol. Cell. Biol. 2; 127-137, 2001. 